\title{
Comparison of the Serum Levels of Trace Elements in Areas with High or Low Rate of Esophageal Cancer
}

\author{
Hamidreza Joshaghani ${ }^{1}$, Honey-sadat Mirkarimi ${ }^{1, *}$, Sima Besharat ${ }^{1}$, \\ Gholamreza Roshandel ${ }^{1}$, Omid Sanaei ${ }^{1}$, Mojgan Nejabat ${ }^{1}$
}

1. Golestan Research Center of Gastroenterology and Hepatology, Golestan University of Medical Sciences

\footnotetext{
* Corresponding Author:
}

Honey-sadat Mirkarimi, BSc of Microbiology, Golestan Research Center of Gasteroentrology and Hepatology, Golestan University of Medical Sciences, 3rd floor, Research Centers' Complex, Sayyad-eShirazi Hospital, Sayyad-e-Shirazi Blv., Gorgan city, Golestan province, Iran Tel: + 981732369210 Fax: + 981732369210

Email: honey_mi8@yahoo.com

Received: 21 Dec. 2016

Accepted: 09 Mar. 2017

\section{ABSTRACT}

\section{BACKGROUND}

There is a critical role for trace elements in cancer prevention. Since northeast Iran is known as a high risk area for esophageal cancer, this study was designed to compare the serum levels of some trace elements in high and low rate areas of Golestan province.

\section{METHODS}

We used 240 fasting serum samples obtained in 2011 from eastern and western parts of Golestan province during the non-communicable diseases' screening program. To carry out laboratory examinations, the samples were firstly deproteinated and then the concentrations of the intended elements were measured by an atomic absorption spectrometer. A total of 227 samples were used in the present study and the remaining 13 samples were excluded due to inappropriate conditions.

\section{RESULTS}

The mean serum level of zinc in the high-risk region was significantly lower than that in the low-risk region. But no significant difference was detected in serum levels of copper, magnesium, and manganese in the low-risk and high-risk regions.

\section{CONCLUSION}

As this study was an ecological study with no comparison between patients with cancer and healthy population, its results cannot be used for the general population. Therefore, complementary studies including case-control studies are suggested for further evaluation of the relationship between these elements and the incidence of esophageal cancer.

\section{KEYWORDS:}

Ecological study; Esophageal cancer; Serum levels; Copper, Magnesium, Manganese, Zinc

\section{Please cite this paper as:}

Joshaghani HR, Mirkarimi HS, Besharat S, Roshandel GR, Sanaei O, Nejabat M.Comparison of the Serum Levels of Trace Elements in Areas with High or Low Rate of Esophageal Cancer. Middle East J Dig Dis 2017;9:81-85. DOI: 10.15171/mejdd.2017.55.

\section{INTRODUCTION}

Esophageal cancer is the $8^{\text {th }}$ most common cancer and the $6^{\text {th }}$ cancer-related cause of death worldwide. ${ }^{1}$ The highest reported incidence rate of esophageal cancer in Iran belongs to Golestan province in the northeast of the country. ${ }^{2,3}$

Trace elements, in low concentrations, are integral parts of the protein structures and are essential for biological enzymatic systems to function normally. For instance, zinc, copper, and manganese are essential elements that play a vital role as cofactors for enzymes. ${ }^{4}$ Previous animal or cell-culture studies have shown that zinc, copper, and manganese are involved in the atherogenesis 
process and carcinogenesis. ${ }^{5}$ And they serve as a cofactor for the enzymes activity responsible in preventing DNA denaturation. ${ }^{6}$

Higher concentrations of zinc are thought to have a cancer preventive role due to the antioxidant properties. ${ }^{7}$ In fact, zinc exerts a protective role against free radicalinduced damage. Reduction in the zinc concentration potentially reduces the anti-carcinogenic effect of vitamin A and possibly influences the host immune response. ${ }^{8}$

Zinc also has an important role in transcription, antioxidation, and DNA repair. Therefore, zinc deficiency may be involved in DNA breakdown, and as a result, oxidative changes may increase the risk of cancer. ${ }^{9}$

Copper is also essential in antioxidant defense, but higher concentrations of copper is associated with neurodegenerative disorders through induction of cellular overgrowth and eventually cancer by induction of free hydroxide radical-DNA damage. On the contrary, copper deficiency may lead to an increase in oxidative damage. ${ }^{7}$

Magnesium deficiency may increase or decrease the risk of carcinogenesis paradoxically, too. ${ }^{4,10}$

This study was designed to evaluate the serum levels of zinc, copper, magnesium, and manganese in two populations living in Golestan province, one from a region with high and the other from a region with low incidence of esophageal cancer.

\section{MATERIALS AND METHODS}

\section{Sample collection:}

We used 240 fasting serum samples obtained in 2011 from eastern and western parts of Golestan province during the Non-Communicable Diseases Surveillance Surveys in the form of the National and Subnational Burden of Diseases, Injuries, and Risk Factors (NASBOD) study. This screening policy has been scheduled to achieve a road map for policy making as they address health gaps in Iranian population and the inequality between provinces.

These samples had been frozen and banked in the central laboratory of the Golestan University of Medical Sciences. To carry out laboratory examinations, the samples were firstly deproteinated and then the concentrations of the intended elements were measured by an atomic absorption spectrometer.

A total of 227 samples were used in the present study and the remaining 13 samples were excluded due to inappropriate conditions.

According to the mean and standard deviation (SD) of the serum levels of copper and zinc in the studies done by Zhang and colleagues and O'Reilly and co-workers, sample size was calculated as $100(95 \% \mathrm{CI}$, power $=80 \%)$ in each group. ${ }^{11}$

Based on the recorded data of the Golestan province cancer registry system and the incidence rate of the esophageal cancer, eastern and western regions of the province were respectively considered as high-risk $(\mathrm{N}=110)$ and low-risk $(\mathrm{N}=117)$ regions for esophageal cancer.

\section{Ethical considerations:}

The study protocol was approved by the local Ethics Committee of Golestan University of Medical Sciences. Informed consent was obtained from all participants before starting the study.

\section{Statistical analysis:}

Data were analyzed using Student $t$ test and MannWhitney $U$ test to compare the mean $( \pm S D)$ of the studied trace elements between the two areas with high- and low-risk esophageal cancer rate.

\section{RESULTS}

Of the 227 cases, 88 were men (38.8\%), and 139 were women $(61.2 \%)$ with a mean $( \pm \mathrm{SD})$ age of 50.12 $( \pm 13.8)$ years. Table 1 compares the demographic features of the studied population between the regions with high and low risk.

\section{DISCUSSION}

In the present study, the mean serum level of zinc in the high-risk region was significantly lower $(1.23 \mathrm{mg} / \mathrm{L})$ than that in the low-risk $(1.43 \mathrm{mg} / \mathrm{L})$ region. Previous studies on different types of cancers also showed significant difference of serum zinc level between patients with cancer and healthy controls. ${ }^{4-6,9,12}$ Serum levels of copper, magnesium, and manganese were not statistically different between the high- and low-risk regions of esophageal cancer in Golestan province.

There have been studies regarding the role of zinc in different cancer development and progression. In a casecontrol study from a high-risk area of esophageal can- 
Table 1: Demographic features of the individuals enrolled from the high- and low-risk regions in the non-communicable diseases screening program in Golestan province

\begin{tabular}{|c|c|c|c|c|}
\hline Variable & & High risk region $(\mathrm{N}=110)$ & Low risk region $(N=117)$ & $P$ value \\
\hline \multirow{2}{*}{ Sex } & Male & $38(34.5)$ & $50(42.7)$ & \multirow{2}{*}{0.206} \\
\hline & Female & $72(65.5)$ & $67(57.3)$ & \\
\hline \multirow{2}{*}{ Living area } & Urban & $42(38.2)$ & $70(59.8)$ & \multirow{2}{*}{0.001} \\
\hline & Rural & $68(61.8)$ & $47(40.2)$ & \\
\hline \multirow{2}{*}{ Age group (years) } & $<50$ & $54(49.1)$ & $56(47.9)$ & \multirow{2}{*}{0.853} \\
\hline & $\geq 50$ & $56(47.9)$ & $61(52.1)$ & \\
\hline
\end{tabular}

As it is shown in table 2 , the mean \pm SD serum level of copper of women residing in the high-risk region was significantly higher than men $(1.49 \pm 0.53 \mathrm{mg} / \mathrm{L}$ vs. $1.28 \pm 0.34 \mathrm{mg} / \mathrm{L}$, respectively; $P=0.02)$.

Table 2: Mean (SD) serum levels of zinc, copper, magnesium, and manganese in the high-risk and low-risk regions of Golestan province for esophageal cancer

\begin{tabular}{lccccc}
\hline \multirow{2}{*}{ Element } & \multicolumn{2}{c}{ High-risk region } & \multicolumn{2}{c}{ Low-risk region } & \multirow{2}{*}{$P$ value } \\
\cline { 2 - 5 } & Mean & SD & Mean & SD & $0.1^{*}$ \\
\hline Copper $(\mathrm{mg} / \mathrm{L})$ & 1.42 & 0.48 & 1.53 & 0.44 & $0.05^{* *}$ \\
\hline Zinc $(\mathrm{mg} / \mathrm{L})$ & 1.23 & 0.74 & 1.43 & 0.76 & $0.32^{*}$ \\
\hline Manganese $(\mathrm{mg} / \mathrm{L})$ & 0.64 & 0.77 & 0.59 & 0.75 & $0.48^{* *}$ \\
\hline Magnesium $(\mathrm{mg} / \mathrm{L})$ & 16.95 & 5.91 & 16.44 & 5.06 & \\
\hline
\end{tabular}

* Student $\mathrm{t}$ test ; ** Mann-Whitney U test

cer in India (Kashmir Valley), no association was found between copper concentration and TP53 mutation status but lower zinc levels were seen in patients with TP53 mutant tumor compared with those with no mutation. In addition, the mean level of copper was significantly higher in patients $(169 \mu \mathrm{g} / \mathrm{dL})$ than controls $(149 \mu \mathrm{g} / \mathrm{dL})$ and the mean level of zinc in patients $(86.8 \mu \mathrm{g} / \mathrm{dL})$ was significantly lower than controls $(96.1 \mu \mathrm{g} / \mathrm{dL}){ }^{2}$

Furthermore, it has been proposed that zinc concentration in tissues is a better marker of cancer development and progression compared with the serum levels. As in a case-control study in China (2005), Abnet and colleagues detected much lower risk of esophageal cancer in subjects with highest quartile of esophageal tissue zinc concentration compared with lowest quartile. In their study, a strong association was found between high tissue zinc concentration and reduced risk of developing esophageal squamous cell carcinoma. But other minerals such as copper did not show such associations. ${ }^{3}$

In a very recent cohort study from this area, Hashemian and co-workers reported an inverse relation between zinc intake and esophageal squamous cell carcinoma (ESCC), although the association was not significant.
Furthermore, a non-linear association was seen between the dietary intakes of selenium, magnesium, and copper and risk of ESCC. Dietary intake of manganese showed no relation with the risk of ESCC. ${ }^{4}$

In contrast there are paradoxical results regarding the zinc level in cancer cases. For example the case-control study by Pasha and colleagues showed a significantly higher plasma level of zinc in patients with cancer compared with healthy controls. ${ }^{13}$

Due to the positive effect of zinc in reducing oxidative stress and improving immune response in patients with cancer there is a significant reverse relationship between the plasma or dietary intake of zinc and risk of cancer. Some authors have even proposed that serum level of zinc can be considered as a marker for evaluating the prognosis of cancer. ${ }^{7,14}$

These conflicts have also been seen about the concentration of copper. Some researchers reported higher serum level of copper in patients with cancer compared with the control group. ${ }^{4,5,9,12,15,16}$ But other studies showed lower serum level of copper in patients with cancer compared with the healthy controls. ${ }^{17}$

Previous studies on the serum level of magnesium 
and manganese are scarce with paradoxical results. Some reported a significantly lower serum level of magnesium and higher serum level of manganese in patients with cancer compared with the control group. ${ }^{4,14}$ On the contrary, patients with lung cancer had a lower serum concentration of manganese compared with the control group in the study reported by Sadat and co-workers. ${ }^{5}$

\section{CONCLUSIONS:}

Among the trace elements measured in the sera of healthy individuals, zinc was the only element with significantly lower serum level in individuals living in the highrisk region compared with those living in the low-risk area.

\section{Limitations:}

Since this work was an ecological study with no comparison between the patients with cancer and healthy population, its results cannot be used for the general population. Therefore, complementary studies including casecontrol studies are suggested for further evaluation of the relationship between these elements and the incidence of esophageal cancer. In addition there may be a confounding association between the residing area as rural or urban sites and the changes in trace elements level that should be noted more in coming studies. Considering the changes in serum levels of trace elements we had a limitation using serum markers as the cancer biomarkers. But considering the large cohort study running in the eastern part of the Golestan province, in the near future we would have the result of measuring these trace elements and other biomarkers in nail and hair of the people residing in this area to compare with serum levels and find a better marker to detect cancer at the very early stages.

\section{CONFLICT OF INTEREST}

The authors declare no conflict of interest related to this work.

\section{REFERENCES}

1. Ferlay J, Shin HR, Bray F, Forman D, Mathers C, Parkin DM. Estimates of worldwide burden of cancer in 2008 : GLOBOCAN 2008. Int J Cancer 2010;127:2893-917.

2. Bird-Lieberman E, Fitzgerlad R. Early of diagnosis of esophageal cancer. Br J Cancer 2009;101:6. doi:10.1038/ sj.bjc. 6605126 .
3. Mahboubi E, Kmet J, Cook P, Day N, Ghadirian P, Salmasizadeh S. Oesophageal cancer studies in the Caspian Littoral of Iran: the Caspian cancer registry. Br J Cancer 1973;28:197-214. doi:10.1038/bjc.1973.138.

4. Cobanoglu U, Demir H, Sayir F, Duran M, Mergan D . Some mineral, trace element and heavy metal concentrations in lung cancer. Asian Pac J Cancer Prev 2010;11:1383-8.

5. Sadat A, Hossain MI, Hossain MK, Reza MS, Nahar Z, Islam SKN, et al. Serum Trace Elements and Immunoglobulin Profile in Lung Cancer Patients. J Appl Res 2008;8:24

6. Cunzhi H, Jiexian J, Xianwen Z, Jingang G, Shumin Z, Lili D. Serum and tissue levels of six trace elements and copper/zinc ratio in patients with cervical cancer and uterine myoma. Biol Trace Elem Res 2003;94:113-22. doi: $10.1385 /$ bter: $94: 2: 113$

7. Pires LV, Pimentel JAC, do Nascimento-Nogueira N, do Nascimento-Marreiro D. Analysis of plasma and erythrocyte zinc levels in premenopausal women with breast cancer. Nutr Hosp 2011;26:293-7.

8. Wang M, Song H, Chen WQ, Lu C, Hu Q, Ren Z, et al. Cancer mortality in a Chinese population surrounding a multi-metal sulphide mine in Guangdong province: an ecologic study. BMC public health 2011;11:319. doi: 10.1186/1471-2458-11-319.

9. Ajayi GO. Copper and zinc concentrations in Nigerian women with breast cancer. Eur J Gynaecol Oncol 2011;32:307-8.

10. Wang M, Xu Y, Pan S, Zhang J, Zhong A, Song H, et al. Long-Term Heavy Metal Pollution and Mortality in a Chinese Population: An Ecologic Study. Biol Trace Elem Res 2011;142:362-79. doi: 10.1007/s12011-010-8802-2.

11. Zhang H-q, Li N, Zhang Z, Gao S, Yin H-y, Guo D-m, et al. Serum zinc, copper, and zinc/copper in healthy residents of Jinan. Biol Trace Elem Res 2009;131:25-32. doi: 10.1007/s12011-009-8350-9

12. Jafari Shobeiri M, Tabrizi A, Atashkhoyi S, Sayyah-Melli M, Ouladsahebmadarek E, Gojazadeh M, et al. Serum Levels of Copper and Zinc, Copper/Zinc Ratio in Patients with Benign and Malignant Ovarian Tumors. Mazandaran Univ Med Sci 2011;21:21-30.

13. Pasha Q, Malik SA, Shah MH. Statistical analysis of trace metals in the plasma of cancer patients versus controls. J Hazar Mater 2008;153:1215-21. doi:10.1016/j. jhazmat.2007.09.115.

14. Oyama T, Kawamoto T, Matsun K, Osaki T, Matsumoto A, Isse $T$, et al. A case-case study comparing the usefulness of serum trace elements $(\mathrm{Cu}, \mathrm{Zn}$ and $\mathrm{Se})$ and tumor markers (CEA, SCC and SLX) in non-small cell lung cancer patients. Anticancer Res 2003;23:605-12.

15. Mazdak H, Yazdkhasty F, Mirkhesht N, Shafieyan M, Behzad E. Serum Iron, Copper, Zinc levels in bladder cancer patients in comparison with healthy individuals. Res Med 2010;34:56-60. 
16. Zowczak M, Iskra M, Torliński L, Cofta S. Analysis of serum copper and zinc concentrations in cancer patients. Biol Trace Elem Res 2001;82:1-8. doi: 10.1385/ bter:82:1-3:001.

17. Khoshdel Z, Naghibalhossaini F, Abdollahi K, Shojaei S, Moradi M, Malekzadeh M. Serum Copper and Zinc Levels Among Iranian Colorectal Cancer Patients. Biol Trace Elem Res 2015;170:294-9. doi: 10.1007/s12011015-0483-4.

18. Labib HA, Hassanein M, Etewa RL. Serum copper is a simple but valuable prognostic marker in B-cell chronic lymphocytic leukemia. Int J Hematol 2014; 100:575-81. doi: $10.1007 / \mathrm{s} 12185-014-1686-8$. 